\title{
Analysis of Food Insecurity Status of Urban Food Crop Farming Households in Cross River State, Nigeria: A USDA Approach
}

\author{
Otu W. Ibok ${ }^{1}$, Idiong C. Idiong ${ }^{2}$, Itoro N. Brown ${ }^{2}$, Iniobong E. Okon ${ }^{2} \&$ Uwemedimo E. Okon ${ }^{1}$ \\ ${ }^{1}$ Department of Agricultural Economics and Resources Management, Akwa Ibom State University, Nigeria \\ ${ }^{2}$ Department of Agricultural Economics and Extension, University of Calabar, Nigeria \\ Correspondence: Otu W. Ibok, Department of Agricultural Economics and Resources Management, Akwa Ibom \\ State University, P.M.B 1167, Uyo, Nigeria. Tel: 234-803-591-4329. E-mail: otuibok@yahoo.com
}

\author{
Received: May 23, 2013 Accepted: June 21, 2013 Online Published: January 15, 2014 \\ doi:10.5539/jas.v6n2p132 URL: http://dx.doi.org/10.5539/jas.v6n2p132
}

\begin{abstract}
The study analyzed food security status of urban food crop farming households in Cross River State. A two-stage sampling technique was used to obtain a sample size of 217 urban food crop farmers in three urban areas in Cross River State namely; Calabar, Ikom and Ugep. The USDA approach was used to analyze and measure the intensity of food insecurity and hunger among farm households in the study area. The result showed that only $12.44 \%$ of urban farmers were food secure, $55.76 \%$ were food insecure without hunger, $25.35 \%$ were moderately food insecure with hunger and $6.45 \%$ were severely food insecure with hunger. Staple food crops such as cassava, yam, rice, and maize were shown to contribute immensely to the food security status of farming households. Buying foods on credit, allowing their children to eat first, and occasionally eating fruit were the coping strategies adopted by urban food crop farming households against food insecurity. The study therefore recommends among other things, that to reduce food insecurity, farmers should be encouraged to produce more cassava, yam, rice and maize, and this staple food crops should be made available and accessible for household consumption.
\end{abstract}

Keywords: food security, urban farming, food crops, USDA approach, Cross River State, Calabar

\section{Introduction}

The greatest problem of the world in recent times has remained the reduction or elimination of hunger and poverty. Various strategies have been adopted most especially increasing food output (tons) per year with the adoption of modern production and processing methods. However in doing this, Wiebe (2003) had opined that the quality and quantity that reaches the final consumer is often not considered. In spite of these efforts, serious food crisis is still persisting in the world. In spite of the variation in the estimates of the food insecure in the world, Wiebe (2003) and FAO (2005a) had reported that a good number (about 800 million persons) of the world's population are facing food insecurity challenge. The World Bank in 1996 as asserted by Gebremedhin (2000) had reported that more than one billion people in the world then never had enough food to enhance their living healthy and productive lives. Abdulaziz (2002) had opined that food insecurity had persisted as a global threat and human tragedy despite the enormous public resources and efforts put into hunger and poverty reduction programs by various governments and agencies in the world. The persistence of hunger in the developing countries in particular implies that the provision of adequate and nutritious food for the growing population would be the major challenge that government will face in the future (Stamoulis, Pingali, \& Shetty, 2004). Food insecurity in many low income countries (especially those in sub-Saharan Africa and South Asia) is endemic and worsening as the year goes by in spite of efforts made to reduce it globally (FAO, 1998; Hazell \& Haddad, 2001; Trueblood \& Shapouri, 2002). It is considered a common phenomenon in Africa and majority of the deaths related to food insecurity are reported to occur in sub-Saharan Africa. Nigeria which is the largest country in Sub- Saharan Africa has a population that is about one-fifth of the total population of the region. The country being endowed with both human and natural resources, has what it takes to build a prosperous economy and provide the basic needs for all its citizens but yet the country is ranked among the poorest nation in the world (Ukehe, 2004). The largest sector is agriculture, contributing about $40 \%$ of the gross domestic product and employing about $70 \%$ of the labour force. The slow growth of agricultural and food production has resulted in growing food imports and food security. Household spend up to $70 \%$ of their income on food and yet nearly $50 \%$ of the children under five are malnourished (Ukehe, 
2004). Recently, Ayodeji (2010, December), asserted that the number of hungry people in Nigeria is over 53 million, which is about $30 \%$ of the country's total population of roughly 150 million; and $52 \%$ live under the poverty line. These are matters of grave concern largely because Nigeria was self sufficient in food production and was indeed a net exporter of food to other regions of the continent in the 1950s and 1960s. Things changed dramatically for the worse following the global economic crisis that hit developing countries beginning from the 1970's onward. The discovery of crude oil and rising revenue from the country's petroleum sector encouraged official neglect of the agricultural sector and turned Nigeria into a net importer of food. By 2009 for example the Federal Ministry of Agriculture estimated that Nigeria was spending over $\$ 3$ billion annually on food imports.

\subsection{Statement of Problem}

Food insecurity remains a fundamental problem in Nigeria. The Food and Agriculture Organization (2002) enlisted the country among countries faced with serious food insecurity problems. The vision of Nigeria to have physical and economic access to food on a continuous basis has therefore continued to remain a mirage (Fakayode, Rahji, Oni, \& Adeyemi, 2009). As at 1986, about 14 million (16\%) Nigeria was food insecure with majority being peasant farming households (Abalu, 1990). Over 40\% of households across all agro-ecological zones in Nigeria face the problem of severe food insecurity (Mariya-Dixton, Akinleye, Oguntona, Nokoe, \& Hariss, 2004). The 2010 MDG report states that the proportion of the Nigerian population living below the hunger threshold increased from $29 \%$ to $7233 \%$ between 2000 and 2009, implying little prospect of achieving the 2015 target of $14.5 \%$. In Nigeria, common approaches used to assess food security situation involve the use of benchmark food security (Idrisa, Gwary, \& Shehu, 2008), consumption expenditure (Omonona \& Agoi, 2007), food supplies (Naiken, 2003), anthropometric methods (Marcoux, 2002), and coping strategies (Idrisa, Gwary, \& Shehu, 2008). Some authors focus more on the outcome of food insecurity such as low weights and extreme hunger, while others care about dietary diversity, with a few more recent studies also considering household perception about their food security (Barrett, 2002). These approaches classify households as either a food secure or a food insecure household. Nevertheless, these methods fail to examine the extent of the severity of food insecurity among households. Therefore, a more intensive approach for food security assessment is necessitated. This study adopts such an approach: the USDA (2000) approach for the analysis of food insecurity in the study area. The study examined the socio-economic profile of urban food crop farming households, their food security status and the coping strategies adopted by the farmers against food insecurity.

\subsection{Literature Review}

FAO, (2002) defined food security as a situation that exist when all people, at all times, have physical, social, and economic access to sufficient, safe, and nutritious food that meets their dietary needs and food preferences for an active and healthy life. This definition means that food insecurity exist when people do not have access to enough and appropriate foods (Barrett, 2002). No matter the definition of food security, there are four distinctive variables central to the attainment of food security. These variables are: food availability, accessibility, utilization, and stability of access. Availability, accessibility and utilization are hierarchical in nature. Food availability is necessary but not sufficient for food accessibility and access is necessary but not sufficient for utilization. In a larger sense, two broad groups of factors determine food security. These are supply side factors and demand side factors. The supply-side factors are those that determine food supply or food availability. In other words, they are determinants of physical access to food at national, household and intra-household levels. The demand side factors, ascertain the level of access that households and individuals has to available food. Therefore, they are determinants of economic access to food or determinants of entitlement to available food (Omonona \& Agoi, 2007).

Several empirical works have been done on food security status of households across the country. Fakayode et al. (2009) using the USDA approach, examined the food security situations of farm households in Ekiti State, Nigeria. They found out that only $12.2 \%$ of the respondents were food secure, $43.6 \%$ were not food insecure without hunger, $35.9 \%$ were moderately food insecure with hunger, and $8.3 \%$ were severely food insecure with hunger. Cassava, yam and their products contribute immensely to the food security status of farm households. These results do not agree with those of Abalu (1999) and Mariya-dixton et al. (2004), which indicated that $84 \%$ and $60 \%$ of the country's households respectively were food secured, while only $16 \%$ and $40 \%$, respectively of Nigerian households are food insecure. In related study, Muhammad-Lawal and Omotesho (2008) highlight the place of cereals in farming households' food security in kwara state. They found out that $60 \%$ of the total households were food secure. Cereals provided $34 \%$ of the farming households total calorie intake and $47 \%$ of protein supply, respectively. Ibrahim, Uba-Eze, Oyewole, and Onuk (2009) assessed the state of food security among urban households in the Federal Capital Territory of Nigeria. The food security scale developed by Freedom from Hunger (FFH) was used to analyze the data. They found out that seventy percent of the respondents were food 
secured, while thirty percent were not food secure in the study area. The major coping strategies adopted against food shortages were the purchase of less preferred food and reduction in the quantity of meals. However, Omonona and Agoi (2007) analyze the food security situation among urban households in Lagos State, Nigeria. The data were analyzed using food security incidence. They found out that food insecurity incidence among urban households in the study area was 0.49 . As age of household heads increases, food insecurity incidence also increases. Household heads between the ages of sixty one and seventy years had the highest food insecurity incidence (at 0.58 ) and least between twenty one and thirty years at 0.30 . Female headed households had the highest food insecurity incidence of 0.49 compared to male headed households at 0.38 . As level of education increases, food insecurity incidence reduces. Household heads that were engaged in professional occupation had relatively low food security incidence at 0.36 compare to those who were traders at 0.48 . Households within the range of $1-4$ and greater than twelve members had the food insecurity incidence ranging between 0.27 and 1.00 respectively. This shows that food insecurity incidence increases as household size increases. There was a decline in food insecurity incidence as income increases from 0.41 for the low-income group to 0.20 for the high-income group.

\subsection{Hypothesis of Study}

Ho: Urban food crop farming households in the study area are not food secure.

Ha: Urban food crop farming households in the study area food secure.

\section{Materials and Methods}

\subsection{The Study Area}

Cross River State occupies an area of about 22,342.176 square kilometers (Quarterly News Letter of the Ministry of Local Government Affairs, Cross River State, 2006). It is located on Latitude $5^{\circ} 25^{\prime} \mathrm{N}$ and longitude $25^{\circ} 0^{\prime} \mathrm{E}$. The soils of Cross River State are ultisol and alfisol but predominantly ultisol, suitable for pineapple production. Cross River State is bounded on the North by Benue State, South by Bight of Bonny, and in the East by Ebonyi and Abia States, while in the West by Republic of Cameroun (Menakaya \& Floyd, 1978). About 2,888,966 people inhabit the area, of which the Efiks, Ejaghams and Bekwarras are the major ethnic groups (Agbor, 2007). Cross River State has the largest rainforest covering about 7,290 square kilometers. It is described as one of Africa's largest remaining virgin forest harboring as many as five million species of animals, insects and plants. The state is located within the evergreen rainforest zone. There are two distinct climate seasons in the area, rainy season, from March to October and dry season from November to February. The annual rainfall varies from $2,942 \mathrm{~mm}$ to $3,424 \mathrm{~mm}$. The average temperature is about $28^{\circ} \mathrm{C}$. Cross River State is characterized by the presence of numerous ecological and zoo-geographically important high gradient streams, rapids and waterfalls. Fishing and subsistence agriculture are the main occupations of the people. Crops grown in the locality include rice, maize, yam, cassava, pineapple, plantain, banana, oil palm, rubber and cocoa among others (Agbor, 2007).

\subsection{Sampling Procedure and Sampling Size}

The population of this study comprise of all urban food crop farming households in Cross River State. Urban food crop farmers are those farmers who cultivated crops like vegetables, root and tubers, and staple crops with one growing season. A two stage sampling technique was used in selecting the sample. The first stage involved the random sampling of three urban areas out of eight major urban areas in Cross River State. The eight urban areas were arranged in an alphabetical order and assign a number to each of them. These numbers were written in separate piece of papers and were put into a basket, then thoroughly mixed. The researcher blindfolded himself, dip his hand into the basket and pick out a number. This process continued until three urban areas were selected namely: Calabar, Ugep, and Ikom. In stage two, a snowball sampling technique was employed to select urban food crop farmers in each urban area. With this approach, the researcher initially contacted few respondents and then asked them whether they know anybody practicing urban farming activities in their residence to recruit future subjects from among the acquaintances. This was done mainly because it was near impossible to get the exact number of urban food crop farmers in each town. The sample size calculator was used to determine the total number of urban farmers that will be interviewed in order to get result that reflect the target population. Sixty seven (67) farmers were interviewed in Calabar, ninety six (96) in Ikom, and Fifty seven (57) in Ugep, using the confidence level of $95 \%$ and confidence interval of $12 \%, 10 \%$, and $13 \%$ respectively. A total of 220 urban food crops farmers were sampled in the study area. Out of 220 urban farmers selected for this study, 217 supplied complete data that were used in the analysis.

For the purpose of this study, the researchers were interested in urban farms in the study area. It was found out that these farms were mostly mixed crop farms. The crops mostly cultivated were: Yam (Dioscorea alata), 
Cassava (Manihot esculenta), Waterleaf (Talinum triangulare), Maize (Zea mays), Pumpkin (Telferia occidentalis), Pepper (Capsicum annum), Melon (Cucumis melo), Okra (Hibiscus esculentus), Potatoes (Ipomea batatas), Pineapple (Ananas comosus), Plantain (Musa paradisiaca), and Banana (Musa acuminata).

\subsection{Analytical Technique}

To assess the food security status of urban food crop farmers, this study adopted the United States Department of Agriculture (USDA) approach for the analysis. The USDA method categorizes households using a constructed food security scale. This scale is a number continuum in a linear scale that ranges between 0 and 10 . The scale measures the degree of food insecurity/hunger experienced by households in terms of a single numerical value. The procedure that determines a household scale fundamentally depends on the household responses to some structured survey questions (These questions are presented in Table 1). A household with a scale value of 6 has responded affirmatively to more questions that are indicators of food insecurity than for a household with a scale value of 3. A household that has not experienced any of the conditions of food insecurity covered by the core questions was assigned a scale value of 0 , while a household that has experience all of them will be scored scale values close to 10 . In general, the set of questions works symmetrically together to provide a measurement tool for identifying, with considerable sensitivity, the level of food insecurity, the level of food insecurity/hunger experience in a household (Bickel \& Nord, 2000).

Table 1. Structured survey questions on food security of the household

\begin{tabular}{llll}
\hline \multirow{2}{*}{ Questions } & \multicolumn{2}{c}{ Responses } \\
\cline { 2 - 3 } & $\begin{array}{l}\text { Often } \\
\text { true }\end{array}$ & $\begin{array}{l}\text { Sometimes } \\
\text { true }\end{array}$ & $\begin{array}{l}\text { Never } \\
\text { true }\end{array}$
\end{tabular}

Do you worry if your food stock will run out before you get another to eat?

Do you have enough resources to acquire enough food?

Could you afford to eat balanced meals?

Do you supplement your children's feed with low cost foods?

Can you afford to feed your children balance meals?

Were your children not eating enough, because you couldn't afford enough food?

Do adults in your household skip meal or cut the size of their usual meals?

Do you eat less than what you feel, you should?

Were you ever hungry, but didn't eat?

Did you lose weight, because there wasn't enough food to eat?

Did you or other adults in your household ever not eat for a whole day because there wasn't enough money for food?

How often did this happen?

Did you ever cut the size of your children's meal because there wasn't enough money for food?

Did any of the children ever skip meals, because there wasn't enough food to eat?

Did any of the children ever not eat for a whole day?

Were the children ever hungry but you just couldn't afford more food?

All questions (1-16) covered the last 12 months period, Sept 2011- Oct 2012. Source:Adapted from USDA 2000.

Coding survey responses for food security scale: Each household's location on the food security continuum is assessed by their response to series of questions about behaviours and experiences known to characterize households, having difficulty in meeting their food needs. To do this, their response to each of the questions 1-16 
in Table 1 were coded as either affirmative or negative. These questions had three response categories namely: "often true", "sometimes true" and "never true". For these questions both "often true" and "sometimes true" were considered as affirmative responses because they indicate that the condition occurred at some time during the year of the study. The distinction between "often true" was, therefore, not used in the scale. In determining the household food security status on the food security scale, the food security scale was first simplified into a small set of categories as in Table 2. Four categories were defined for this purpose- food secure, food insecure without hunger, food insecure with hunger (moderate) and food insecure with hunger (severe) (Bickel \& Nord, 2000).

Food secure households: These are households that show zero or minimal evidence of food insecurity. The group's value ranges between $0-2.32$ on the food security scale.

Food insecure without hunger households: These households experience inadequacy in food supplies and food budgets, feel anxiety about the sufficiency of their food to meet basic needs and make adjustments to their food budgets and types of food served. This group's value ranges from $2.33-4.56$ on the food security scale.

Moderately food insecure households with hunger: These groups of households have their food intake reduced such that the household adults have repeatedly experience the physical sensation of hunger but spare the children this experience. The group's value ranges from $4.57-6.53$ on the scale.

Table 2. USDA food security scale

\begin{tabular}{|c|c|c|c|}
\hline $0-2.32$ & $2.33-4.56$ & $4.57-6.53$ & $6.54-10.0$ \\
\hline \multirow[t]{3}{*}{ Food secure } & \multicolumn{3}{|c|}{ Food insecure } \\
\hline & \multicolumn{3}{|c|}{ Food insecure with hunger } \\
\hline & Food insecure Witnout nunger & "Moderate" & "Severe" \\
\hline
\end{tabular}

Source: Adapted from USDA (2000).

Severely food insecure households with hunger: Households in this group have their children also suffer reduced food intake and hunger, and adults' reductions in food intake are more dramatic. The group's value on the food security scale ranges from $6.54-10.0$ on the food security scale.

Descriptive statistics such as frequency count and percentages were used to analyze the socio-economic profiling and coping strategies adopted by farmers.

\section{Results and Discussion}

Socio-economic profiling of respondents: Table 3 shows the socio-economic profile of urban food crop farmers. About $58.52 \%$ of the farmers were within the age of $30-49$ years. Within this age range, the respondents are expected to be very active on the farm and more responsive to agricultural extension programmes. This could also lead to a boost in agricultural activities as Anyanwu, Agwu, and Musa (2001) recognized that young people are more likely to be energetic and have the capacity to use innovation. The sex distribution of the urban farmers showed $51.6 \%$ of females and $48.4 \%$ of males. Most of the farmers $(90.8 \%)$ were married. Only $2.3 \%$ of the farmers did not have any formal education. This is in contrast to rural areas where over $20 \%$ were illiterate (Adeyemo \& Kuhlmann, 2009). About $75.2 \%$ of the farmers had gone through primary and secondary education while $22.6 \%$ had their higher diploma and degree. The educational status of urban food crop farmers will enable them to acquire knowledge and skill and this will help to increase their productivity and reduce food insecurity. The household consisted of 11 members on average with a standard deviation of 6 members. Household size is important because it increases the number of consumers putting pressure on household resources particularly food and household with high dependency ratio are particularly prone to food insecurity. Agriculture serves as a part time occupation because majority (61.3\%) of the respondents were not full time farmers. This means that urban farming serve as additional source of income to the farmers. This agrees with Egbuna (2009), that urban agriculture is a viable intervention strategy for urban poor to earn extra income. The result also showed an estimated average annual income per household of N372, $040(\$ 2,325.00)$. 
Table 3. Socio-economic profiling of the respondents

\begin{tabular}{|c|c|c|}
\hline Variables & Frequency & Percentages \\
\hline \multicolumn{3}{|l|}{ Age: } \\
\hline $20-29$ & 14 & 6.45 \\
\hline $30-39$ & 56 & 25.80 \\
\hline $40-49$ & 71 & 32.72 \\
\hline $50-59$ & 45 & 20.74 \\
\hline $60-69$ & 24 & 11.06 \\
\hline \multirow[t]{2}{*}{ Over 70} & 7 & 3.23 \\
\hline & 217 & 100 \\
\hline \multicolumn{3}{|l|}{ Sex: } \\
\hline Male & 105 & 48.4 \\
\hline \multirow[t]{2}{*}{ Female } & 112 & 51.6 \\
\hline & 217 & 100 \\
\hline \multicolumn{3}{|l|}{ Marital Status: } \\
\hline Single & 14 & 6.5 \\
\hline Married & 197 & 90.8 \\
\hline Widow & 5 & 2.3 \\
\hline \multirow[t]{2}{*}{ Divorcee } & 1 & 0.4 \\
\hline & 217 & 100 \\
\hline \multicolumn{3}{|l|}{ Educational Level: } \\
\hline No Formal Education & 5 & 2.3 \\
\hline Primary Education & 37 & 17.1 \\
\hline Secondary Education & 126 & 58.1 \\
\hline \multirow[t]{2}{*}{ Tertiary Education } & 49 & 22.6 \\
\hline & 217 & 100 \\
\hline \multicolumn{3}{|l|}{ Household Size: } \\
\hline $1-5$ & 24 & 11.1 \\
\hline $6-10$ & 103 & 47.5 \\
\hline $11-15$ & 59 & 27.2 \\
\hline $16-20$ & 18 & 8.3 \\
\hline \multirow[t]{2}{*}{ Above 21 Persons } & 13 & 5.9 \\
\hline & 217 & 100 \\
\hline \multicolumn{3}{|l|}{ Employment Status: } \\
\hline Farming & 84 & 38.7 \\
\hline \multirow[t]{2}{*}{ Non-farming } & 133 & 61.3 \\
\hline & 217 & 100 \\
\hline \multicolumn{3}{|c|}{ Estimated Annual Income( $\$ 1$ = N160): } \\
\hline $\mathrm{N} 1,000-\mathrm{N} 99,999$ & 52 & 23.9 \\
\hline N100,000 - N199, 999 & 21 & 9.6 \\
\hline N200,000 - N299, 999 & 25 & 11.5 \\
\hline N300, $000-\mathrm{N} 399,999$ & 20 & 9.2 \\
\hline N400, 000 - N499, 999 & 35 & 16.1 \\
\hline N500, $000-\mathrm{N} 599,999$ & 25 & 11.5 \\
\hline \multirow[t]{2}{*}{$>\mathrm{N} 600,000$} & 39 & 18.2 \\
\hline & 217 & 100 \\
\hline
\end{tabular}

Source: Computed from field data (2012). 
Cropping practices and land use: The result in Table 4, reveals that the majority (46.5\%) of the urban food crop farmers had commercial farm (these are farms meant to generate income for the farmers), $41.5 \%$ of the farmers had community garden (were land is divided into smaller plot for individual users), and $12 \%$ of the farmers had backyard garden (these are plot around homes). In terms of the land area cultivated by urban food crop farmers, majority $(66.82 \%)$ of the farmers cultivated less than 1 hectares of land, $27.65 \%$ cultivated between 1 and 2 hectares of land and only $5.53 \%$ cultivated more than 2 hectares of land. The average land holding in the study area was 0.63 hectares. Fragmentation of the land holdings was an issue, as farmers often have more than one location for their farms due to factors such as soil fertility and accessibility to land. Most respondents farmed on communal land and leased land. Greater percentage (96.3\%) of urban food crop farmers practiced mixed cropping. A considerable number (2.8\%) also practiced sole cropping; very few practiced mixed farming, while the remaining practiced both sole and mixed cropping. Liverpool-Tasie (2011) found out that farmers who practiced mixed cropping often have more profitable and efficient farm. Also mixed cropping has the advantage over sole cropping as crop diversification guards against crop failure, leading to higher yield stability and reduced risk. Most households cultivated yam and cassava, which were usually intercropped with other crops like maize, and vegetables. It was observed that urban food crop farmers farm whenever they could find empty spaces in the cities. They grow leafy vegetables, pepper, okra, and some food crops mainly for the informal market in other to meet their more basic needs, also to better their households. Traditional leafy vegetables which grow fast and absorb few inputs are among their important products, because they contribute to the inexpensive vegetable supply of the urban lower classes.

Table 4. Cropping practices and land area cultivated by the respondents

\begin{tabular}{lll}
\hline Variables & Frequency & Percentage \\
\hline Type of Urban farm & & \\
Backyard Garden & 26 & 12 \\
Community Garden & 90 & 41.5 \\
Commercial Farm & 101 & 46.5 \\
& 217 & 100 \\
Land Area Cultivated (ha) & & \\
$0.001-0.1$ & 23 & 10.59 \\
$0.11-0.2$ & 7 & 3.23 \\
$0.21-0.3$ & 88 & 40.55 \\
$0.31-0.4$ & 7 & 3.23 \\
$0.41-0.8$ & 20 & 9.22 \\
$1-2$ & 60 & 27.65 \\
$>2$ ha & 12 & 5.53 \\
& 217 & 100 \\
Cropping practice & & \\
Sole cropping & 6 & 2.8 \\
Mixed cropping & 209 & 96.3 \\
Mixed/sole cropping & 1 & 0.5 \\
Mixed Farming & 1 & 0.5 \\
& 217 & 100 \\
\hline
\end{tabular}

Source: Computed from field data (2012).

Food security status and crop contributions to farm household food security: Based on the food security analysis results, derived using the USDA (2000) approach earlier described, few of the urban farmers' households $(12.44 \%)$ were food secure, while most of them (87.56\%) were food insecure at different levels of food insecurity (Table 5). The result shows that $55.76 \%$ of farm households were food insecure without hunger, $25.35 \%$ were moderately food insecure with hunger and $6.45 \%$ were severely food insecure with hunger. This result agrees with Fakayode et al. (2009) which indicated that $12.2 \%$ of the country's households were food secured and $87.8 \%$ were food insecure. This is a great concern, if the Millennium Development Goal of halving 
the population of food insecure households by 2015 is to be achieved. The daily household food consumption of the respondents consists mainly of yam, cassava and their products, which made up $36 \%$ of the total food consumption from both household own food production and food purchases. Cereals which comprise of rice and maize constitute $32.88 \%$, Cowpea constituted $16.28 \%$, and Meat/fish constituted $14.84 \%$ of the total food consumption. This implies that a deficit in the availability of popular cereals (like rice and maize) and roots and tubers (like yam and cassava and their products) in the area could mean serious food insecurity problems for the households. Cereals, cassava and yam must therefore, be accorded necessary consideration in any effort, at enhancing food security in the study area.

Table 5. Food security and daily food consumption of the respondents

\begin{tabular}{lll}
\hline Variables & Frequency & Percentages \\
\hline Food Security & & \\
Food secure & 27 & 12.44 \\
Food insecure without hunger & 121 & 55.76 \\
Food insecure with hunger (moderate) & 55 & 25.35 \\
Food insecure with hunger (severe) & 14 & 6.45 \\
& 217 & 100 \\
Kinds of food consume daily & & \\
Yam & 207 & 16.52 \\
Yam Flour & 16 & 1.28 \\
Cassava flour & 16 & 1.28 \\
Garri & 212 & 16.92 \\
Rice & 213 & 17.0 \\
Maize & 199 & 15.88 \\
Cowpea & 204 & 16.28 \\
Meat \& Fish & 186 & 14.84 \\
& $1253^{*}$ & 100 \\
\hline
\end{tabular}

Source: Computed from field data (2012); * Number exceeds 217 due to multiple responses.

Coping strategies: Table 6 shows the coping strategies adopted by food crop farmers' household against food insecurity. The strategies span from eating once a day to picking leftover food at social function. About $67.75 \%$ of urban farmers occasionally allow their children to eat first, $36.92 \%$ occasionally ate fruit, and $71.96 \%$ buy's food on credit. Therefore, buying food on credit, allowing children to eat first, and eating of fruit were the coping strategies mostly used by farmers against food insecurity.

Table 6. Percentage distribution of respondents according to strategies used against food insecurity

\begin{tabular}{llllll}
\hline Coping Strategy & $\begin{array}{l}\text { Very often } \\
(\%)\end{array}$ & $\begin{array}{l}\text { Regularly } \\
(\%)\end{array}$ & $\begin{array}{l}\text { Occasional } \\
(\%)\end{array}$ & $\begin{array}{l}\text { Never } \\
(\%)\end{array}$ & Rank \\
\hline Eating once a day & 3.26 & 1.4 & 38.6 & 56.74 & $4^{\text {th }}$ \\
Allowing children to eat first & 7.48 & 4.21 & 67.75 & 20.56 & $2^{\text {nd }}$ \\
Eating of fruit & 24.3 & 3.27 & 36.92 & 35.51 & $3^{\text {rd }}$ \\
Selling of assets & 13.08 & 0.47 & 16.98 & 69.33 & $5^{\text {th }}$ \\
Buying food on credit & 7.48 & 0.93 & 71.96 & 19.63 & $1^{\text {st }}$ \\
Picking of leftover food at social functions & 4.65 & - & 3.72 & 91.63 & $6^{\text {th }}$ \\
\hline
\end{tabular}

Source: Computed from field data (2012). 


\section{Conclusion}

The belief that majority of urban households in Nigeria are not faced with serious food insecurity problems appears erroneous. In this study $98.16 \%$ of urban food crop farming households were not food secure, only $1.84 \%$ were food secure. To cope with this high level of food insecurity, allowing their children to eat first, occasionally eating fruits and buying food on credit were the coping strategies adopted by household heads in the study area. The study also shows that that staple food crops especially yam, cassava, rice and maize play a crucial role in the food security drive of urban households. In line with the study findings therefore, there is an urgent need to remedy food insecurity problems in the urban areas of Nigeria. To remedy the food insecurity problems in the area, there should be increased production of cassava, yam, rice and maize by the farmers to enhance availability vis-avis accessibility for urban household consumption. This can be achieved through easy access to land and subsidized inputs for farmers in the study area. Also, policy makers should endeavor to tailored extension practices/packages to assist this particular class of farmers who are in the urban areas.

\section{References}

Abalu, G. O. I. (1999). The attainment of food security in Nigeria: The role of resource constrained in Nigeria farmers. National Farming Systems Research Network Bulletin, 2, 197-206.

Abdulaziz, T. (2002). Corruption: Sustainable food security for all by 2020. Ibadan: IFPRI, 172-175.

Agor, G. (2007). The economics of population growth and changes in demographic structure. In MOFINEWS (2007). Cross River State privation exercise- journey so far.

Anyanwu, A. C., Agwu, A. E., \& Musa, A. P. (2001). Adoption of gender specific innovation by women in state. Journal of Agricultural Extension, 5, 64-72.

Ayodeji, A. (2010). Concerning food security in Nigeria. West Africa Insight. Retrieved from http://www.westafricainsight.org/articles/PDF/81

Barrett, C. ( 2002). Food security and food assistance programs. In G. Rausser and B. Gardner (Eds.), Handbook of agricultural economics, 30-50. Amsterdam: Elsevier.

Benson, T. (2004). Assessing Africa's food and nutrition security situation 2020. Africa conference brief 1, IFPRI.

Bickel, G., \& Nord, M. (2000). Guide to measuring household food security (pp. 1-82). Alexandria: USDA.

Egbuna, N. E. (2009). Urban Agriculture: A strategy for poverty reduction in Nigeria. CBN.

Fakayode, S. B., Rahji, M. A. Y., Oni, O. A., \& Adeyemi, M. O. (2009). An assessment of food security situations of farm Households in Nigeria: A USDA approach. The Social Sciences, 4(1), 24-29.

Food and Agriculture Organization (FAO). (1998). Urgent action needed to combat hunger as number of undernourished in the world increases. Retrieved December 15, 2005, from www.fao.org

Food and Agriculture Organization (FAO). (2002). The state of food insecurity in the world 2001 (pp. 1-55). Rome: FAO.

Food and Agriculture Organization (FAO). (2005). FAO warns world cannot afford hunger. Retrieved December 15, 2005, from www.fao.org

Gebremedhin, T. G. (2000). Problems and prospects of the world food situation. Journal of Agribusiness, 18(2), 221- 236.

Hazell, P., \& Haddad, L. (2001). Agricultural research and poverty reduction. Food, Agriculture and the Environment discussion paper, No. 34.IFPRI. Washington D.C.

Ibrahim, H., Uba-Eze, N. R., Oyewole, S. O., \& Onuk, E. G. (2009). Food security among urbanhouseholds: A case study of Gwagwalada area council of the Federal Capital Territory Abuja, Nigeria. Pakistan Journal of Nutrition, 8(6), 810-813. http://dx.doi.org/10.3923/pjn.2009.810.813

Idrisa, Y. I., Gwary, M. M., \& Shehu, H. (2008). Analysis of food surety status among farming household in Jere Local Government of Borno State, Nigeria. Journal of Tropical Agriculture, Food, Environment and Extension, 7(3), 199-205.

Liverpool-Tasie, L. S., Kuku, O., \& Ajibola, A. (2011). A review of literature on agricultural productivity, social capital and food security in Nigeria. NSSP Working Paper, 21, 1-53. 
Marcoux, A. (2002). Sex differentials in under nutrition: A look at survey evidence. Population and Development Review, 28, 275-284. http://dx.doi.org/10.1111/j.1728-4457.2002.00275.x

Mariya-Dixton, B., Akinleye, E., Oguntona, S., Nokoe, R., Sanus, A., \& Hariss, E. (2004). Nigeria food consumption and nutrition survey (2001-2003 summary) (pp. 1-30). Ibadan: International Institute for Tropical Agriculture (IITA).

Menakaya, J. C., \& Floyd, B. N. (1978). Macmillan junior atlas for Nigeria. Lagos: Macmillan, 28-30.

Millennium Development Goals. (2010). Millennium development goals (Nigeria) 2010 report. Retrieve from http:// www.ng.undp.org/mdgs/Final-MDG-report-2010.pdf

Muhammad-Lawal, A., \& Omotesho, O. A. (2008). Cereals and farming households food security in kwara state, Nigeria. Agricultural Journal, 3(3), 235-240.

Naiken, L. (2003). FAO methodology for estimating the prevalence of undernourishment. Proceedings of international scientific symposium on measurement and assessment of food deprivation and undernutrition. Rome, June 26-28.

Omonona, B. T., \& Agoi, G. A. (2007). An analysis of food security situation among Nigerian urban households: Evidence from Lagos State, Nigeria. Journal of Central European Agriculture, 8(3), 397-406.

Quarterly news letter of the ministry of local government affairs. (2006). Description of Cross River State (pp. 4-8).

Stamoulis, K. G., Pingali, P., \& Shetty, P. (2004). Emerging challenges for food and nutrition policy in developing countries. Special issues on globalization of food systems: Impact on food security and nutrition. Electronic Journal of Agricultural and Development Economics, eJADE, 1(2), 154-167.

Trueblood, M., \& Shapouri, S. (2002). Food insecurity in the least developed countries and the international response (pp. 29-31). Long Beach: AAEA.

Ukehe, E. (2004). Modernizing small holder agriculture to ensure food security and gender empowerment: Issues and policy (pp. 1-23). Intergovernmental group for twenty four. Washington, DC.

Wiebe, K., Soule, M. J., Narrod, C., \& Brenneman, V. E. (2003). Resource quality and agricultural productivity: A multi-country comparison (pp. 1504-1507). Washington D.C.: Edward Elgar.

\section{Copyrights}

Copyright for this article is retained by the author(s), with first publication rights granted to the journal.

This is an open-access article distributed under the terms and conditions of the Creative Commons Attribution license (http://creativecommons.org/licenses/by/3.0/). 